\title{
'Ducking and Diving': How Political Issues Affect Equivocation in Japanese Political Interviews
}

\author{
OFER FELDMAN \\ Faculty of Policy Studies, Doshisha University, Kyoto, Japan \\ ofeldman@mail.doshisha.ac.jp \\ KEN KINOSHITA \\ Faculty of Policy Studies, Doshisha University, Kyoto, Japan \\ kekinosh@mail.doshisha.ac.jp \\ PETER BULL \\ Department of Psychology, University of York, UK \\ peter.bull@york.ac.uk
}

\begin{abstract}
This paper examines how Japanese leading politicians cope with the communication problems posed during televised political interviews. Based on data gathered during the year 2012-13, the paper replicates and modifies the Theory of Equivocation to detail the responsiveness of national and local level politicians (and for comparison also of non-politicians) to interview questions. Its main focus is on the extent to which Japanese politicians equivocate during televised programs, and the reasons underlying this equivocation. Overall, the paper aims to identify the motives behind interviewees' equivocation, thereby to also assess the significance of these talk shows in the broader context of political communication in Japan.
\end{abstract}

\section{Introduction}

Politics, at its core, is about persuasion. And in the era of television, political communicators, politicians, and government officials alike try to use this medium to explain to the general public their motives, objectives, and policy positions, to justify their activities, and to affect the standards by which citizens evaluate political groups, policies, and issues. Televised interviews are one of the important genre through which political communicators try to frame the political milieu and influence the way citizens make sense of politics. Such interviews provide the 'overhearing audience' (Heritage, 
1985) easy and accessible ways to identify, understand, and evaluate social and political issues and distinguish among the individuals and groups that endeavor to solve related problems and the measures used. Despite the increasing number and importance of these televised talk shows, especially in Japan, ${ }^{1}$ there is still a lack of information on the communicative patterns and responsiveness of Japanese politicians to interview questions (with a few exceptions, e.g. Tanaka, 2004; Furo, 2001: 37-52). This study aims to fill some of the existing gaps in the literature. It tries to highlight the selected, if limited, aspects of political interviews, focusing in particular on the question of how members of the Japanese National Parliament (Diet) as well as local level political leaders (and of non-politicians) cope with the questions posed to them during televised political interviews. Its particular focus is on equivocation, the strategic use of evasive and ambiguous language. Colloquially, this may be referred to in English as 'ducking and diving', and in Japanese as 'heppirigoshi', literally 'behaving apprehensively with one's buttocks stuck out', metaphorically as being vague or indecisive.

\section{Political interviews}

As a genre of the mass media, televised political interviews are set up to produce face-to-face confrontational and challenging encounters with journalists and politicians. They have their own distinctive features, and a defined set of rules and norms dominated by the roles and functions of the interviewers and the interviewees. First, these interviews are staged performances that take place with the participation of journalists and political officers or experts, and in which the ultimate addressee is absent from the actual event. The interviews are enacted for the benefit of an 'overhearing audience' whose probable expectations shape what is being said and how. Both the interviewer and the interviewee (politician or expert) will have the general viewers in mind. The interviewer will consider the consumers of their talk show and simultaneously colleagues in their organization; success or failure in their performance can determine their future career and their status with their peers and within the corporation. For politicians, attending an interview program is often viewed as their best tool to speak 'directly' to hundreds of thousands of people; an opportunity to advance their ideas and thoughts to the electorate; an occasion for enhancing positive images of themselves and their political groups; and a ground for attacking their political opponents and challengers. Second, there is a 'turn-taking system', which noticeably defines the conflicting functions of interviewers and interviewees, as both are

1 Among these programs, known as tōron bangumi, or debate programs, are: NHK's Nichiyō tōron [Sunday's Debate]; Nippon Television Network's U-ēkuappu! Purasu [Wake-Up! Plus]; TV Asahi Network's Hōdō sutēshon sandēe [News Station Sunday]; TBS network's jiji hōdan [Free Talk on Current Events]; TV Tokyo's Tase yasuhiro no shūkan nyūsu shinsho [Tase Yasuhiro's Weekly News Book]; Fuji Television's Bīesu fuji raivu puraimu nyūsu [BS Fuji Live Prime News]; and a variety of show programs including TV Asahi's Bìto takeshi no TV takkuru [Beat Takeshi TV Tackle] and Yomiuri TV network's Takajin no soko made itte iinkai [Committee to Say Up to There]. In Japanese vowels can either be short or long; a diacritical mark, e.g. ō, $\overline{\mathrm{u}}, \overline{\mathrm{e}}$, or $\bar{a}$ over the vowel indicates that it is a long vowel. 
working to generate discourse for the 'overhearing audience' in a two-way process. Thus, the interviewers are responsible for determining the topic for discussion, monitoring the duration of the discourse, and adhering to specific ritualistic patterns, including introducing the interviewees and concluding the interview session. At the same time, interviewers also pose questions and challenge interviewees to specify and explain their positions and views on a variety of issues, and they are expected to do so by keeping a balance between adversarialism and objectivity, maintaining a stance of neutrality by not favoring specific politicians or a given political group. The interviewees' task is to reply to these questions to best effect for both themselves as individuals and for the political groups or institutions which they represent (e.g. Clayman and Heritage, 2002). Challenging these role allocations would be regarded as a violation of the primary rules that structure the political interview.

Another distinctive feature of political interviews is interviewee vagueness, evasiveness, or equivocal communication style (the terms are interchangeable as suggested by Bull, 1994), as they hedge from providing direct answers to the questions they are asked. Thirteen strategies used by politicians to avoid giving direct answers were identified by Jucker (1986), 35 different forms of non-reply were identified by Bull (2003, based on Bull and Mayer, 1993), while eight evasive tactics utilized by political interviewees were identified by $\mathrm{Hu}$ (1999). Reply rates, defined as the proportion of questions which receive a direct answer (Bull, 2003), are very low. Less than $40 \%$ were reported for televised interviews broadcast in the UK (Harris, 1991; Bull, 1994) and for Taiwan (Huang, 2009), while less than $10 \%$ were reported for political interviews in Japan (Feldman, 2004, pp. 76-110).

\section{The theory of equivocation}

Bavelas and her colleagues (Bavelas et al., 1988; Bavelas et al., 1990) proposed that it is the interview situation, rather than politicians' devious and slippery personalities, that create strong pressures towards equivocation. They regard equivocation as a form of indirect communication, ambiguous, contradictory, and tangential, which may also be incongruent, obscure, or even evasive (Bavelas et al., 1990: 28).

Bavelas et al. (1990) theorized that individuals typically equivocate when they are placed in an 'avoidance-avoidance conflict' (or a communicative conflict), whereby all possible responses to a question have potentially negative consequences for the respondent, but nevertheless a response is still expected by interlocutors and audience. Such conflicts are especially prevalent in interviews with politicians because of the nature of the interview situation. Thus, interviewers may have an interest in controversial, sensitive, and divisive issues, and thereby put pressure on politicians to choose among undesirable alternatives, in which all potential responses may damage the image of the politicians or alienate part of the electorate (Bavelas et al., 1990: 246-9). Notably, the argument underlying the work of Bavelas et al. (1990) is that equivocation does not occur without a situational precedent. In other words, although it is individuals 
who equivocate, such responses must always be understood in the situational context in which they occur, known as the Situational Theory of Communicative Conflict (STCC).

Bavelas et al. (1990) further proposed that equivocation can be conceptualized in terms of four dimensions, namely sender, content, receiver, and context. Thus, the sender dimension refers to the extent to which the response is the speaker's own opinion; a statement is considered more equivocal if the speaker fails to acknowledge it as his or her own opinion, or attributes it to another person. Content refers to comprehensibility, an unclear statement being considered more equivocal. Receiver refers to the extent to which the message is addressed to the other person in the situation, the less so the more equivocal the message. Context refers to the extent to which the response is a direct answer to the question; the less the relevance, the more equivocal the message.

A modification of equivocation theory has been proposed by Bull and his colleagues in terms of what are called threats to face (Bull et al., 1996; Bull, 2008). Bull and his colleagues proposed that questions might be formulated in such a way that politicians constantly run the risk of making face-damaging responses (responses which make themselves and/or their political allies look bad, and/or constrain their future freedom of action). Bull et al. further proposed that politicians need to defend three faces (personal, political party, and that of significant others), and that communicative conflicts may occur when all the principal ways of responding to a question are potentially facedamaging, thereby creating pressures towards equivocation.

This paper utilizes this framework of the equivocation theory to analyze televised interviews with Japanese politicians and to detail their attitudes toward responding to a wide range of questions posed to them during interviews. Specifically, the focus is on the extent to which Japanese politicians equivocate during televised programs, and the reasons underlying this equivocation. Overall, the paper aims to identify the motives behind interviewee equivocation, thereby to also assess the significance of these talk shows in the broader context of political communication in Japan.

\section{Method}

\section{The interviews}

The study was based on 194 live interviews (145 with politicians, 49 with nonpoliticians) broadcast over a period of 14 months (May 2012-June 2013) on three television programs: Puraimu Nyūsu (Prime News) (147 interviews), Shin Hōdō 2001 (New Broadcast 2001) (25 interviews), and Gekiron Kurosufaya (Gekiron Crossfire) (22 interviews). These programs are transmitted nationwide in Japan on a daily or weekly basis, except for rare occasions when replaced by coverage of special events such as the high-school baseball championship games held each summer. Puraimu Nyūsu is broadcast through BS (Broadcasting Satellite) every day from Mondays through Fridays (20:00 to 21:55). Shin Hōdō 2001 every Sundays (7:30 and 8:55), and Gekiron Kurosufaya broadcasts through BS every Saturday (10:00 and 10:55). 
All the programs feature interviews with public figures such as members of the National Diet, government officials, and decision-makers from various social and economic sectors of society. Questions are posed mainly by prominent journalists who also function as moderators. Their role is to open and close the interview, invite other guests to present questions to the interviewees, and challenge unsatisfactory responses. There are also additional questions from scholars or experts (referred to as komenteitā or 'commentators') in such areas as public policy, social affairs, or economics. The moderators typically control the interviews, while the commentators participate only when invited to do so. Interaction characteristically takes the form of question-response sequences, with questions from the moderators and commentators, and responses from the interviewees. The three programs at the center of this research differ from each other in their broadcast time, length of the interview session, the moderators' questioning style, and pursuit of detailed replies. Consequently, there is diversity in replies between the different programs (Feldman et al., 2015, pp. 81-83).

Notably, the interviews in this study were broadcast both before and after the general election of 16 December 2012 for the House of Representatives (the lower house of the National Diet). Since September 2009, the majority of seats in the lower house had been held by the Democratic Party of Japan (DPJ) (or Minshutō), and its coalition partner, the People's New Party (PNP) (Kokuminshintō). However, the election resulted in a disastrous defeat for the DPJ and an overwhelming victory for the Liberal Democratic Party (LDP) (Jiyūminshutōo), and its partner the New Kōmei Party (NKP) (Kōmeitō); they won a majority in the House, and consequently established a new coalition administration. The result was a transfer of power from a centre-left to a conservative and nationalist political grouping; hence, a significant realignment in the Japanese political spectrum.

\section{The data}

The analysis was based on interviews broadcast seven and a half months before the election, and six and half months afterwards (referred to subsequently as the first and second sessions). Over the whole period of 14 months (426 days), the three television programs featured a total of 1,356 interviews (3.2 interviews per day) with 745 interviewees ( 359 in the first session and 386 in the second session), several of whom were interviewed more than once. On an individual basis, there were interviews with 236 different individual politicians from the Diet (e.g., the prime minister, state ministers, and secretary generals of political parties); 13 different politicians from the local level (e.g., governors of Tōkyō and Ōsaka and mayors), and 496 different experts (e.g., university professors, economists, and retired politicians, 'experts' who are 'competent' to speak on particular issues, making sense of them for the layperson - they are invited to share with the audience their knowledge and insight, or to confirm the credibility of the news or current affairs being discussed, and their views are taken seriously precisely because they have been defined as 'experts'). The interviews took place either in small groups or in one-on-one sessions. However, interviews with a single interviewee were 
selected whenever possible, in order to focus primarily on question-response sequences between interviewer and interviewee. Only questions asked by the moderators and the 'commentators' were included in this study.

From these 1,356 interviews, interviewees were selected as follows:

1. Every week one national politician from the coalition government (whichever coalition was in power) was selected, and a second from the opposition parties. To assess the communication style employed by the Diet members, there was also a non-politician every week, and, when available, a local level politician (these were interviewed relatively infrequently).

2. As some of the politicians, especially high-echelon members (e.g., leaders of political parties, government ministers) gave more than one interview during the period of the study, to examine as varied a sample as possible only one interview per person was included, usually the longest in duration.

In determining which national level politicians to include in the study, special consideration was allotted to the relative proportions of television appearances of members of each of the political parties. In total, there were 236 interviews with individual Diet members, made up as follows (figures for the first and second sessions in parentheses): LDP $100(37,63), \operatorname{DPJ} 76(58,18), \mathrm{NKP} 13(5,8)$, Your Party (YP) (Minna no tō) $10(5,5)$, Japanese Communist Party (JCP) (Kyōsantō), $6(4,2)$, Japan Restoration Party (JRP) (Nippon ishin no kai) $8(2,6)$, Tomorrow Party of Japan (TPJ) (Nippon mirai no tō) 4 (3,1), the Social Democratic Party (SDP) (Shamintō) 3 (2, 1), the New Renaissance Party (NRP) (Shintō kaikaku) 3 (2, 1), People's Life Party (PLP) (Seikatsu no tō), formally People's Life First (PLF) (Kokumin no seikatsu ga daiichi) 4 $(3,1)$, the Sunrise Party of Japan (SPJ) (Tachiagare nippon) 2 (2, o), New Party DaichiTrue Democrats (NPD) (Shintō Daichi-Shinminshu) 2 (2, o), the PNP 1 (1,0), The Sunrise Party (SP) (Taiyō no tō) 1 (1, o), Tax Cuts Japan, Anti-TPP, Nuclear Phaseout Realization Party (TCJP) (Genzei nippon, han TTP-datsu-genpatsu wo jitsugen suru tō), $1(1,0)$, Green Wind (GW) (Midori no kaze) $1(0,1)$, and one unaffiliated politician $1(1,0)$.

To represent these proportions appropriately, 133 interviews with national Diet politicians were selected, drawn from the different political parties as follows: LDP, 61 (20, 41); DPJ, 38 (31, 7); JRP, 7 (3, 4); NKP, 6 (3, 3); YP, 6 (4, 2); PLP, 3 (2, 1); JCP, 3 (2, 1); SDP, 2 (2, o); PNP, 1 (1, o); NRP, 1 (1, o); SPJ, 1 (1, o); TCJP, 1 (1, o); NPD, 1 (1, o); GW, $1(0,1)$; one unaffiliated politician, $1(1,0)$.

3. For comparison purposes, there were 12 interviews with local politicians $(6,6)$ and 49 with non-politicians $(29,20)$.

In total, the sample consisted of 194 interviewees. Only 25 of the interviews took place on a one-to-one basis, 21 with two interviewees, and 148 with three interviewees or more. The longest interview lasted 45 minutes and 44 seconds, the shortest only 3 minutes, the mean duration was 24 minutes, 36 seconds. The number of questions per interview ranged from 2 to 98 , with a mean of 26.2 questions. In total, 5,084 questions were analyzed. 


\section{Procedure}

Interviews from the three programs were recorded using a DVD recorder. A verbatim transcript was made of each selected interview. Based on a methodology used by the first author in previous research in Japan (Feldman, 2004, pp. 80-88), criteria for identifying questions and responses were determined. Two coding sheets were devised for analyzing the structure and verbal content of the interviews: the first for interviewer questions, the second for interviewee responses.

Questions. 'Questions' were regarded as utterances made by interviewers in order to elicit information from interviewees. Following Jucker (1986), questions were divided into two main groups: prefaced and non-prefaced.

The total number of questions analyzed was 5,084, distributed across the television programs as follows: Puraimu Nyūsu 3,868 (76.1\%); Shin Hōdō 2001957 (18.8\%); Gekiron Kurosufaya 259 (5.1\%). The high proportion drawn from the first program reflects the fact that it is broadcast five days a week for almost two hours. In this program, questions were posed by Sorimachi Osamu ${ }^{2}$ (member of the editorial board and political desk commentator), Yagi Akiko and Shimada Ayaka (both newscasters). In Shin Hōdō 2001, questions were usually presented by the moderators Suda Tetsuo (news anchor and TV Fuji news commentator) and Yoshida Kei (newscaster), and the political commentator Hirai Fumio (Fuji Television, News Desk, vice-chairman of the board of commentators). In Gekiron Kurosufaya, questions were asked principally by the main host, Tahara Souichirō (journalist) and by Murakami Yuko (announcer).

Responses. The second coding sheet comprised several questions intended to analyze interviewee responses. Four were based on the four Bavelas et al. (1990) dimensions of sender, receiver, content, and context. However, whereas in the Bavelas et $a l$. procedure raters are asked to mark on a straight line the degree of equivocation for each dimension, in this study each dimension was assessed on a six-point Likert-type scale ('neutral' was not included in these six possible responses, in order to force the rater to make a selection on the relative degree of equivocation).

Further modifications were made to Bavelas et al.'s (1990) four dimensions as follows:

1. Sender. Assessed by the question: 'To what extent is the response the speaker's own opinion (intention, observation, ideas)?' The scale consisted of six options, ranging from (1) 'It is obviously his/her personal opinion/ideas, not someone else's', to (6) 'It is obviously someone else's opinion/ideas.'

There are many instances in which interviewees clearly revealed (using the pronouns meaning 'I' and 'me') their own ideas and observation regarding a given political event. On the other hand, there are numerous cases in which they used no

\footnotetext{
2 Personal names are given in the Japanese order, i.e. family name first.
} 
personal pronoun at all, leaving it unclear whose opinion they were expressing, or in which they used expressions that did not pinpoint the sender, such as 'we', 'our party', 'politicians', 'it seems ... 'or 'it is said ... ', as we see from the following exchange between Sorimachi and Kasai Akira, the JCP's Deputy Party Policy Committee. Sorimachi asked the Diet member about the Japan Coast Guard:

Sorimachi: From the perspective of JCP, is the size of the Japan Coast Guard today small?

Kasai: It is said that they do what is needed as a necessary police activity

(Puraimu Nyūsu, 22 November 2012).

Here Kasai does not express his own opinion: his words 'It is said' is about as equivocal on the sender dimension as one can get! 'It' might be the way things are perceived by either his party or the Japan Coast Guard, or by anyone else, the media, perhaps a common gossip; in any case this is not his own personal view.

2. Receiver. Assessed by the question 'To what extent is the message addressed to the other person in the situation?'

Because the original Bavelas et al. (1990) scales were devised for the analysis of dyadic conversations, the intended receiver is always clear. However, when the scale is extended to broadcast news interviews, there arises the issue of multiple receivers. Thus, when an interviewee responds to a question, it is not always clear whether the intended receiver is the interviewer, or possibly another interviewee. It may also be the general public, a particular segment of the public, or another politician or group of politicians, all of whom can be referred to as the 'overhearing audience' (Heritage, 1985).

The coding sheet in this study was intended to address this issue by posing the following question: 'To what extent is the message addressed to the person(s) who asked the question?', i.e. the interviewer (either the moderator or the commentators). Possible recipients were assessed on a six-point scale, ranging from (1) 'obviously addressed to the moderators or the commentators' to (6) 'Addressed to other people.'

Consider the following exchange between Kakizawa Mito, the Vice Chairperson of the Policy Research Council of YP, and Suda, which illustrates an occurrence where it is not clear to whom Kakizawa's reply is aimed at (it could be members of the JRP who attend the interview in the studio, or anybody else) and hence equivocal on the receiver dimension.

Suda: I will ask now Kakizawa from YP, is it possible [for your party] to merge with the JRP, this [topic] has also become now the focus of the news.

Kakizawa: When appearing on this program I looked forward enormously to decide on this, well, it is up to policy, policy is important (Hōdō 2001, 25 November 2012).

3. Content. Assessed by the question 'How clear is the message in terms of what is being said?' The six options aimed to evaluate the various degrees of equivocation 
ranging from (1) 'Straightforward, easy to understand, only one interpretation is possible', to (6) 'Totally vague, impossible to understand, no meaning at all'.

An example of a vague and ambiguous reply is identified in the following extracts taken from the interview with Morimoto Satoshi, the Defense Minister, as the talk focused on the deployment of Osprey multi-mission hybrid American aircraft in Japan. While Tahara, the interviewer, is manipulating a model of the aircraft, he noted:

Tahara: The airplane is taking off this way, humm, and goes down this way.

Morimoto: It changes the nacelle, rotates it, changing the mode, like a helicopter it can rescue human life [move and] bring down Marine Corps, and has an amazing speed with its fixed wings.

Tahara: What speed can it reach?

Morimoto: More than double, but its radius of action is more than four times

(Gekiron Kurosufaya, 21 July 2012).

Morimoto's reply is incomprehensible, hence he completely fails to answer the question. Instead of indicating the speed of the aircraft in terms of miles or kilometers per hour, he gives some comparison figures, but it is not clear to what these numbers relate. It might be assumed that he was comparing the performance of the discussed aircraft with the helicopter used today in Japan, the Boeing Vertol CH-46 Sea Knight.

4. Context. The question used to assess this dimension was, 'To what extent is this a direct answer to the question?' (Bavelas et al., 1990). The six options ranged from: (1) 'This is a direct answer to the question asked', through (6) 'Totally unrelated to the question.'

An example illustrating a reply totally unrelated to the question is taken from an interview where Tahara challenged Edano Yukio, Minister of Economy, Trade and Industry, regarding the resumption of the activities of the Öi Nuclear Power Plant, located in the town of Ōi, Fukui Prefecture. In the weeks previous to this interview, the government approved stress tests of two reactors (out of four) of the Ōi nuclear plant and the submitted safety action plan as satisfactory and confirmed safety standards. To prevent the rise of electricity charges and an estimated power shortage of $18 \%$ in the summer of 2012, the government concluded the two reactors needed to be resumed. Minister Edano was of the opinion that the two reactors were safe enough to be restarted and there was a need for their resumption. In the following weeks, the nuclear crisis management team of the Japanese Nuclear and Industrial Safety Agency announced that the Japanese government will introduce new safety standards for nuclear power plants, but that this agency might not be involved with this. Other officials did not accept this explanation, as they saw the government explanation as inconsistent with the demands of local people that opposed the operation of the nuclear plants. As the dispute continued, Minister Edano was interviewed by Tahara and expressed the view that the nuclear accident in the Fukushima Daiichi nuclear power plant in March 2011 
evolved to such a disastrous accident because the earthquake and the tsunami melted the fuel and that such an occurrence would not happen in Ōi Nuclear Power Plant, as the ways to avoid this were checked 'triple, quadruple, and quintuple times', so it should be alright.

Tahara: So if that is all right, then, that means a restart [of the nuclear plan]?

Edano: Umm-, so, that, umm well, that, oh-, after the safety has been recognized, then, well, if it is not going to restart, it has to be realized how difficult it is [the situation is going be]. Right now we are doing our very best to obtain the peoples' understanding (Gekiron Kurosufaya, 5 May 2012).

Obviously, Edano has not replied to the question if the government is going to restart the nuclear power plant following the safety check. In his response, Edano reveals instead that it is important to receive the understanding of the people in the neighborhood, referring probably to the economic and energy consequences if the plant is not going to soon resume its operation. Should Edano have answered the question by stating that the government will indeed resume the nuclear plant activities, this might have caused a social turmoil in light of the opposing mood in the surrounding areas, as more residents are concerned about a catastrophe similar to that of Fukushima. On the other hand, Edano cannot say the government will withdraw from its plan to activate the plant since then the central regime might appear as incompetent. For these reasons, Edano evaded the question by affirming that there is a need to keep a dialogue with the people to gain their 'understanding.'

One important point to be noted is that a message can be equivocal on any of the four above dimensions. So the content may be perfectly clear (unequivocal in terms of content), but not a direct answer to the question (equivocal on the context dimension).

In addition to these four questions, there were two additional questions to identify the key topics at the center of interviewer enquiry and interviewee response, and to distinguish the issues at stake in the response to each question.

5 and 6. Subject of enquiry/response. Two separate questions were intended to identify the primary focus of the interviewer's enquiry and the focus of the interviewee's response: Question 5 was, 'What is the main content of the question about?' Question 6 was, 'What is the main content of the response about?' Each of these two questions were subdivided (and coded) with respect to six criteria which are detailed below, all mutually exclusive, on the content of the questions and answers (Notably, there was not even one case in which the subjects of enquiry and response were not of an identical criteria):

1. Knowledge of a certain topic or a fact or lack of it (mainly requesting responses to the five Ws and one $\mathrm{H}$ : what, where, who, why, when, and how). An example is a question posed by Tahara to Morimoto, the Defense Minister, about the 
deployment of Osprey aircraft in Japan: 'What is the speed of this aircraft?' (Gekiron Kurosufaya, 21 July 2012);

2. Human affairs/ Significant others (i.e., others' performance at work, impressions on their activities, evaluation of their ability, characteristics, personality, attitudes, and thoughts, and human relationship). For example: A question by Sorimachi to Azuma Shōzō, the Secretary General of the PLF, about his party's leader Ozawa Ichirō: 'Why when I ask the leaders of the "third force" [aimed to challenge the DPJ and the LDP] such as Hashimoto [Tōru, Mayor of Ōsaka City] and Ishihara [Shintarō, the Governor of Tōkyō, both co-leader of the Japan Restoration Party] if they hate Ozawa, they shy away from responding? Is it because they don't want to cooperate with him? Is that so?' (Puraimu Nȳusu, 16 November 2012);

3. Political and Social institutions (e.g., impressions, opinion, and judgments on the activities, attitudes, views, thoughts and ideas within political parties, party factions, and the media). For example: Tahara challenged Sengoku, the DPJ's acting chairman of the Policy Research Council: 'Well, Hmmm. In short, I [perceive] the Nuclear power plant problem as an important one, but, on the other hand, Nuclear power plant er-, the trade deficit is rapidly increasing, from this viewpoint er-, neither newspapers nor television say anything [in this regard]. Er., Mr. Sengoku [what is your opinion]'? (Gekiron Kurosufaya, 2 June 2012);

4. Political process (i.e., involving procedures of decision-making and course of action in the government, the bureaucracy, and between political parties). For example, Tahara asked Ishihara Nobuteru, the LDP's Secretary General: 'In the event of deliberation in the House of Councillors, obviously the LDP prepares to issue a censure motion [is that so]'? (Gekiron Kurosufaya, 7 July 2012);

5. Political commitment (promises regarding courses of action, pledges, and public obligation). For example, in an interview with Motegi Toshimitsu, Chairperson of the LDP's Affairs Research Council, he is asked by Yoshida: 'When approximately do you intend to submit [to the Diet] this LDP's proposal [regarding the unified bill on mutual pension and welfare pension]'? (Shin Hôdô 2001, 13 May 2013);

6. Issues (opinions, stances, and views on policy issues, on social, economic, political and other problems and topics on the public agenda).

Issues in the question-response sequences: If in the previous questions (5 and 6) category (6) Issues was selected, the research coder had to follow and to answer an open-ended question: 'What is the issue (problem, or topic) at the core of the question/response sequences?' The rater identified the issues at the focus of the discussion between the interviewers and the interviewees and listed them one by one. It was later clustered in related categories as detailed below. 


\section{Coding}

The coding on the above seven questions was conducted initially by a welltrained graduate student. The training process involved studying the dimensions of the equivocation theory and a coding of a sample of 300 questions from the interviews while working closely with the main authors. The rater usually received the transcripts of several interviews and did the coding work independently. Upon completion of a set of interviews, a meeting was arranged with the main authors to discuss any problem that arose during the coding. This was resolved immediately through discussion. An inter-coder reliability study of a sample of 300 questions was conducted with an undergraduate who was familiar and experienced with coding televised questions and response sessions. His analysis was performed independently of the main coder and resulted in a high level of agreement: The Pearson's correlation coefficients were 0.72 (for the sender dimension), 0.73 (receiver), 0.85 (content), and 0.82 (context), all $\mathrm{p}<0.001$ level. A reliability study on the issue-non-issue (the six categories listed in questions 5 and 6) for the 300 questions from the sample showed a Cohen's (1960) kappa of 0.72 , and a further reliability study on the 19 issues (see below) of 300 questions from the sample showed a Cohen's (1960) kappa of 0.79 when compared with the main rater.

\section{Results and discussion}

The analysis was based on 194 interviews with individual interviewees (i.e., not interviews with two or more interviewees simultaneously), drawn from three television channels. There were 145 interviews with politicians (133 Diet members, 12 local level politicians), and 49 interviews with non-politicians. A total of 5,084 questions were identified. Politicians were asked 3,748 questions ( $73.7 \%$ of total questions: Diet members 3,342 questions, local level politicians 406 questions). The remaining 1,336 questions $(26.3 \%)$ were posed to non-politicians.

The 194 interviews were analyzed to explore interviewees' responses to questions in terms of the four Bavelas et al. (1990) dimensions (sender, content, receiver, and context). From Table 1 it can be seen that of the 5,084 questions included in this study, only $509(10 \%)$ of the interviewees' replies undoubtedly reflected their personal opinion and ideas, not someone else's (sender dimension): National level politicians had 298 such replies $(8.9 \% \%$ of the replies they gave), local politicians $69(17.0 \%)$, and nonpoliticians 142 (10.0\%); Only 17 replies (0.3\%) were explicitly addressed to the person who asked the question (receiver): National level politicians had 12 such replies ( $0.4 \%$ of the replies they gave), local politicians one (0.2\%), and non-politicians $4(0.3 \%)$. Merely $1,969(38.7 \%)$ were straightforward, easy to understand, with only one interpretation (content): National level politicians had 1,279 (38.3\% of the questions they were asked), local politicians 164 (40.4\%), and non-politicians 526 (39.4\%). Finally, of the 5,084 questions included in this study, 2,260 (43.6\%) were direct answers to the question asked: National level politicians had 1,384 ( $41.4 \%$ of the questions they were asked), local politicians 177 (43.6\%), and non-politicians 699 (52.3\%). 
Table 1. Complete, full reply on each of the four dimensions

\begin{tabular}{lllll} 
Dimensions & National politicians & Local politicians & Non-politicians & Total \\
\hline Sender & 298 & 69 & 142 & 509 \\
& $(8.9 \%)$ & $(17 \%)$ & $(10.6 \%)$ & $(10.0 \%)$ \\
Receiver & 12 & 1 & 4 & 17 \\
& $(0.4 \%)$ & $(0.2 \%)$ & $(0.3 \%)$ & $(0.3 \%)$ \\
Content & 1,279 & 164 & 526 & 1,969 \\
& $(38.3 \%)$ & $(40.0 \%)$ & $(39.4 \%)$ & $(38.7 \%)$ \\
Context & 1,384 & 177 & 699 & 2,260 \\
& $(41.4 \%)$ & $(43.6 \%)$ & $(52.3 \%)$ & $(43.6 \%)$ \\
Total $\dagger$ & 3,342 & 406 & 1,336 & 5,084 \\
\hline
\end{tabular}

Note: $\dagger$ The Total represents the complete number of replies members of a given group gave during the interviews.

In all, the table shows a striking level of equivocation by both national and local level politicians during televised political interviews. Politicians equivocate extensively more than non-politicians, and national level Diet members equivocate notably more than local level politicians, especially on the sender and the content dimensions.

The next set of analyses is focused on the subject of enquiries and responses. The data were initially divided into issues (2,753 of the 5,084 questions, $54.2 \%$ ), and non-issues $(2,331,45.8 \%)$. Non-issues were further subdivided into the following five categories: (1) Knowledge of a certain topic/fact or lack of it (537, 10.6\%); (2) Human affairs (382, 7.5\%); (3) Political and Social institutions (742, 14.6\%); (4) Political process (547, 10.8\%); (5) Political commitment (123, 2.4\%).

The issues at the heart of the interview sessions were clustered into 19 categories on the following topics: 1 . Government Bureaucracy (e.g., functioning of officials in the different governments ministries) (684 questions); 2. Foreign Policy and Diplomacy (e.g., relations with the USA, China, and Korea) (456); 3. Economy (286); 4. Energy and Nuclear Power (261); 5. National Security (e.g., USA bases in Okinawa Islands, disputed islands with South Korea and China, tension with North Korea) (193); 6. Earthquakeand Tsunami-Affected Fukushima's (and other areas) Reconstruction Efforts (165); 7. Campaign Strategies (e.g., nomination of candidates, electorates' mobilization) (124); 8. TPP (Trans-Pacific Partnership) (97); 9. Constitution (e.g., revision, interpretation) (88); 10. Intra-Party Politics (e.g., strategy within a political party) (70); 11. Local Autonomy (65); 12. Diet Affairs Management (65); 13. Consumption Tax and Financial Affairs (61); 14. Cabinet and Government Performance (e.g., appointment of ministers, functioning of the cabinet) $(52)$; 15. Interparty Cooperation (e.g., building grand coalition) (26); 16. Parties' Policy Beliefs and Preferences (e.g., objective of political parties) (21); 17. Public Opinion (opinion polls, support for political parties or issues) (16); 18. Diet's Dissolution (13); (19) Yasukuni Shrine (10). 
Table 2. Comparisons of the means, $S D$, standard error of the means, and t-value of the four dimensions for issues and non-issues

\begin{tabular}{lllllll}
$l$ & $N$ & Mean & SD & Standard error of the mean & T-value \\
\hline \multirow{2}{*}{ Sender } & Issue & 2,753 & 3.25 & 1.194 & 0.023 & -0.889 \\
& Non-issues & 2,331 & 3.28 & 1.387 & 0.029 & \\
Receiver & Issue & 2,753 & 4.04 & 0.629 & 0.012 & $6.221^{* * *}$ \\
& Non-issues & 2,331 & 3.92 & 0.751 & 0.016 & \\
Content & Issue & 2,753 & 2.22 & 1.134 & 0.022 & $9.303^{* * *}$ \\
& Non-issues & 2,331 & 1.93 & 1.051 & 0.022 & $1.891^{*}$ \\
Context & Issue & 2,753 & 2.39 & 1.535 & 0.029 & \\
& Non-issues & 2,331 & 2.31 & 1.565 & 0.032 & \\
\hline
\end{tabular}

Notes: ${ }^{* * *}: \mathrm{p}<0.001,{ }^{*}: \mathrm{p}<0.10$.

Mean ranges between 1 and 6 .

Table 2 details the means, SD, Standard error of the means, and the t-value of the issues and non-issue-related questions along the four dimensions. Only the receiver, content, and the context dimensions are significant. The table reveals that when interviewees are asked questions regarding non-issues (i.e., on familiarity with a topic or an event, opinion on the activities and attitudes of significant others and political groups, views on the political process and on their pledges and obligations), they tend to equivocate less than when they are invited to share their opinions and beliefs on political and social issues. In other words, in comparison to non-issues, when addressing questions related to issues, interviewees tend to direct their replies toward audience other than the interviewers (receiver dimension), to offer less easy to understand and more complex replies (content dimension), and to not provide a full answers to the questions (context dimension). This suggests perhaps that communicative conflicts, resulted in indirect, ambiguous, and tangential responses, are more often to occur when interviewees are asked on social and political issues rather than when they are asked on non-issues related topics.

A closer look at the issues that interviewees try most often to equivocate on are detailed below.

\section{Equivocation by National Diet politicians}

First, Table 3 focuses on the national Diet members specifying those issues on which they equivocated along the four dimensions. The table reveals that Diet members tend to equivocate predominantly in regard to two issues: the economy and issues regarding energy and nuclear power. The latter related to the Great East Japan Earthquake of 11 March 2011, and the consequent tsunami, which did considerable damage in the region, especially to the Fukushima nuclear power station. In both cases, Diet members equivocated along the four dimensions. 
Table 3. Diet members' responses on issues during televised interviews

\begin{tabular}{|c|c|c|c|c|c|c|c|c|}
\hline & \multicolumn{2}{|c|}{$\begin{array}{l}\text { Sender } \\
\text { dimension }\end{array}$} & \multicolumn{2}{|c|}{$\begin{array}{l}\text { Receiver } \\
\text { dimension }\end{array}$} & \multicolumn{2}{|c|}{$\begin{array}{l}\text { Content } \\
\text { dimension }\end{array}$} & \multicolumn{2}{|c|}{$\begin{array}{l}\text { Context } \\
\text { dimension }\end{array}$} \\
\hline & Beta & S.E. & Beta & S.E. & Beta & S.E. & Beta & S.E. \\
\hline (Constant) & $\begin{array}{l}4.701^{* * *} \\
(28.237)\end{array}$ & 0.166 & $\begin{array}{l}4.064^{* * *} \\
(43.508)\end{array}$ & 0.093 & $\begin{array}{l}2.293^{* * *} \\
(13.274)\end{array}$ & 0.173 & $\begin{array}{l}2.456^{* * *} \\
(10.461)\end{array}$ & 0.235 \\
\hline $\begin{array}{l}\text { Gender (female) } \\
\text { [160 questions] }\end{array}$ & $\begin{array}{l}-0.542^{* * *} \\
(-5.414)\end{array}$ & 0.100 & $\begin{array}{c}0.027 \\
(0.480)\end{array}$ & 0.056 & $\begin{array}{l}0.273^{* * *} \\
(2.624)\end{array}$ & 0.104 & $\begin{array}{c}0.155 \\
(1.097)\end{array}$ & 0.141 \\
\hline Age & $\begin{array}{l}-0.023^{* * *} \\
(-7.792)\end{array}$ & 0.003 & $\begin{array}{l}-0.002 \\
(-0.905)\end{array}$ & 0.002 & $\begin{array}{l}-0.001 \\
(-0.444)\end{array}$ & 0.003 & $\begin{array}{l}-0.003 \\
(-0.775)\end{array}$ & 0.004 \\
\hline $\begin{array}{l}\text { National security } \\
\text { [155 questions] }\end{array}$ & $\begin{array}{l}0.415^{* * *} \\
(4.196)\end{array}$ & 0.099 & $\begin{array}{l}0.140^{* *} \\
(2.523)\end{array}$ & 0.055 & $\begin{array}{l}-0.081 \\
(-0.789)\end{array}$ & 0.103 & $\begin{array}{r}0.254^{*} \\
(1.824)\end{array}$ & 0.139 \\
\hline $\begin{array}{l}\text { Constitution } \\
\text { [49 questions] }\end{array}$ & $\begin{array}{l}0.366^{* *} \\
(2.247)\end{array}$ & 0.163 & $\begin{array}{l}0.389 * * * \\
(4.266)\end{array}$ & 0.091 & $\begin{array}{c}0.004 \\
(0.023)\end{array}$ & 0.169 & $\begin{array}{r}0.441^{*} \\
(1.922)\end{array}$ & 0.229 \\
\hline $\begin{array}{l}\text { Foreign policy/diplomacy } \\
\text { [259 questions] }\end{array}$ & $\begin{array}{c}0.108 \\
(1.276)\end{array}$ & 0.085 & $\begin{array}{c}0.058 \\
(1.226)\end{array}$ & 0.048 & $\begin{array}{l}-0.097 \\
(-1.107)\end{array}$ & 0.088 & $\begin{array}{l}0.288^{* *} \\
(2.410)\end{array}$ & 0.120 \\
\hline $\begin{array}{l}\text { Intra-party politics } \\
\text { [61 questions] }\end{array}$ & $\begin{array}{l}-1.146 * * * \\
(-7.678)\end{array}$ & 0.149 & $\begin{array}{l}-0.103 \\
(-1.227)\end{array}$ & 0.084 & $\begin{array}{l}-0.320^{* *} \\
(-2.067)\end{array}$ & 0.155 & $\begin{array}{l}0.371^{*} \\
(1.761)\end{array}$ & 0.210 \\
\hline $\begin{array}{l}\text { Energy/nuclear power } \\
\text { [158 questions] }\end{array}$ & $\begin{array}{l}0.377^{* * *} \\
(3.840)\end{array}$ & 0.098 & $\begin{array}{l}0.228^{* * *} \\
(4.131)\end{array}$ & 0.055 & $\begin{array}{l}0.217^{* *} \\
(2.128)\end{array}$ & 0.102 & $\begin{array}{l}0.463^{* * *} \\
(3.343)\end{array}$ & 0.138 \\
\hline $\begin{array}{l}\text { Economy } \\
\text { [117 questions] }\end{array}$ & $\begin{array}{l}0.237^{* *} \\
(2.138)\end{array}$ & 0.111 & $\begin{array}{l}0.132^{* *} \\
(2.115)\end{array}$ & 0.062 & $\begin{array}{r}0.209^{*} \\
(1.811)\end{array}$ & 0.115 & $\begin{array}{l}0.436 * * * \\
(2.786)\end{array}$ & 0.157 \\
\hline
\end{tabular}


Table 3. Continued

\begin{tabular}{|c|c|c|c|c|c|c|c|c|}
\hline & \multicolumn{2}{|c|}{$\begin{array}{l}\text { Sender } \\
\text { dimension }\end{array}$} & \multicolumn{2}{|c|}{$\begin{array}{l}\text { Receiver } \\
\text { dimension }\end{array}$} & \multicolumn{2}{|c|}{$\begin{array}{l}\text { Content } \\
\text { dimension }\end{array}$} & \multicolumn{2}{|c|}{$\begin{array}{l}\text { Context } \\
\text { dimension }\end{array}$} \\
\hline & Beta & S.E. & Beta & S.E. & Beta & S.E. & Beta & S.E. \\
\hline $\begin{array}{l}\text { TPP } \\
\text { [47 questions] }\end{array}$ & $\begin{array}{l}-0.474^{* * *} \\
(-2.821)\end{array}$ & 0.168 & $\begin{array}{c}0.137 \\
(1.452)\end{array}$ & 0.094 & $\begin{array}{l}-0.037 \\
(-0.214)\end{array}$ & 0.174 & $\begin{array}{c}0.398^{*} \\
(1.681)\end{array}$ & 0.237 \\
\hline $\begin{array}{l}\text { Campaign strategies } \\
\text { [108 questions] }\end{array}$ & $\begin{array}{l}-0.116 \\
(-0.024)\end{array}$ & 0.115 & $\begin{array}{l}0.273^{* * *} \\
(4.220)\end{array}$ & 0.065 & $\begin{array}{l}-0.057 \\
(-0.474)\end{array}$ & 0.120 & $\begin{array}{l}-0.315^{*} \\
(-1.934)\end{array}$ & 0.163 \\
\hline $\begin{array}{l}\text { Reconstruction efforts } \\
\text { [90 questions] }\end{array}$ & $\begin{array}{l}0.304^{* *} \\
(2.459)\end{array}$ & 0.124 & $\begin{array}{l}0.329^{* * *} \\
(4.744)\end{array}$ & 0.069 & $\begin{array}{l}-0.180 \\
(-1.403)\end{array}$ & 0.128 & $\begin{array}{c}0.136 \\
(0.779)\end{array}$ & 0.174 \\
\hline $\begin{array}{l}\text { Diet affairs } \\
\text { Management [ } 59 \text { questions] }\end{array}$ & $\begin{array}{l}-0.485^{* * *} \\
(-3.234)\end{array}$ & 0.150 & $\begin{array}{r}0.143^{*} \\
(1.702)\end{array}$ & 0.084 & $\begin{array}{c}0.168 \\
(1.082)\end{array}$ & 0.156 & $\begin{array}{l}0.460^{* *} \\
(2.174)\end{array}$ & 0.211 \\
\hline $\begin{array}{l}\text { Policy beliefs and } \\
\text { Preferences [15 questions] }\end{array}$ & $\begin{array}{c}0.318 \\
(1.116)\end{array}$ & 0.285 & $\begin{array}{c}0.283^{*} \\
(1.770)\end{array}$ & 0.160 & $\begin{array}{l}-0.037 \\
(-0.127)\end{array}$ & 0.295 & $\begin{array}{l}0.309 \\
(0.770)\end{array}$ & 0.401 \\
\hline $\begin{array}{l}\text { Consumption tax and } \\
\text { financial affairs [ } 40 \text { questions] }\end{array}$ & $\begin{array}{l}0.396^{* *} \\
(2.203)\end{array}$ & 0.180 & $\begin{array}{l}0.329^{* * *} \\
(3.261)\end{array}$ & 0.101 & $\begin{array}{r}0.316^{*} \\
(1.693)\end{array}$ & 0.187 & $\begin{array}{l}0.244 \\
(0.961)\end{array}$ & 0.254 \\
\hline$F(14)$ & $19.974^{* * *}$ & & $5.009^{* * *}$ & & $2.266^{* * * *}$ & & $2.492^{* * *}$ & \\
\hline Adjusted $\mathrm{R}^{2}$ & 0.133 & & 0.031 & & 0.010 & & 0.012 & \\
\hline$N$ & 1,730 & & 1,730 & & 1,730 & & 1,730 & \\
\hline
\end{tabular}

Notes: ${ }^{* *}: \mathrm{p}<0.01{ }^{* *}: \mathrm{p}<0.05,{ }^{*}: \mathrm{p}<0.10$.

Entries are unstandardized regression coefficients ( $b$ 's) and standard errors.

Figures in parenthesis indicate the t-value. 
In the case of the energy/nuclear power, questions on the debate about the use of nuclear power as a major element of electricity production and the future dependence on nuclear power met with equivocal replies; so were questions on nuclear safety, nuclear waste disposal, and the reviving of nuclear power plants in Japan. Consider the following response to a question regarding nuclear power from an interview with Prime Minister Noda Yoshihiko:

Suda: Now, Prime Minister, regarding energy measurements. This [issue] is also gathering attention. Hummm, it is understood that under Noda's administration you have launched a policy of zero [never using] nuclear power plant by 2030s. Meanwhile, er, you have resumed the construction of the nuclear power plants in Ōma [a town located in Aomori Prefecture in northern Japan] and in Shimane [Prefecture]. This, as has been said [here], is a contradiction. Well, do you consider clarifying this [contradiction] in your zero nuclear power plant [policy] for the 2030s in the [DPJ's] manifest?

Noda: Well, in the conference on energy and environment, er-, we considered, as an innovative energy and environment strategy, and as a political objective, not to shake the policy of making society independent from nuclear power plant in 2030s, and under this policy, there are in fact many specific problems. And we will sincerely continue negotiations with the people involved, showing flexibility is the basic thing. Then in 2030s, everything such as the circumstances of the global energy, and the extent to which the renewable energy will be used [will differ] [and thus] it is difficult right now to make any definite prospects. In conclusion, the basic strategy we have this time is that we must have both humility and flexibility [in dealing with this issue] (Shin Hôdô 2001, 16 September 2012).

Obviously, Noda is faced with a difficult question. He has to resolve a clear contradiction in his public policy and to justify it with regard to the future commitments of his party. Thus, if he denies that there is an ongoing reconstruction of nuclear power plants following his cabinet decision, he may be perceived as a liar. If however he enters into a debate seeking to justify this contradiction and admits that his administration supports the reconstruction of these plants, he may also be seen in a bad light, given his party's previous pledges to a policy of zero nuclear power. However, rather than getting into this debate, Noda equivocates by talking about what his party proposed at a recent conference on energy and the environment, emphasizing that flexibility and humility are the basic attitudes one has to show, adding that nobody can foresee the future of the global community or make any concrete commitments. Thereby, he seeks to defend both his own face and that of his administration. Notably, Noda now shows a complete lack of determination, in stark contrast to the strong political beliefs he expressed in his first speech as Prime Minister on 2 September 2011, when he confirmed that the government would continue to phase out nuclear power by neither building new nuclear power plants nor extending the life spans of outdated ones. However, by 
May 2012, nuclear power plants sitting idle in the wake of the Fukushima disaster were restarted in order to help Japan's immediate demands for energy, despite overwhelming public opposition. Not only does Noda not answer the question he was asked (context dimension), he also relates mostly views to WE (the party, the government) (sender), and when he mentioned 'we will sincerely continue negotiations with the people involved', it is not clear if the people involved refers to government bureaucrats, local residents, or the public at large (content).

Questions with regard to the economy are also met often with equivocation, particularly with regard to policy regarding deflation, and the effect of the so-called Abenomics, the economic policies of Prime Minister Abe Shinzō, including a massive bond-buying campaign along with structural reforms and stimulus from the central government. For example, in the following exchange between the interviewer Murakami and Suga Yoshihide (Chief Cabinet Secretary), the latter is asked about the strategy of Prime Minster Abe to increase the price index and the level of wage increases he hoped to achieve. Before asking the question, however, Murakami cites a comment from an economist that the market does not believe that the price index will increase by $2 \%$ as the government wishes, and that the only significant change in the economy will probably be a growth in government-led exports, following the depreciation of the yen. If, the expert opined, the price increase of $2 \%$ will be realized as the Bank of Japan expects, wages will probably rise by $3-4 \%$ and this is not desirable as company costs will increase. Based on this premise, the interviewer turns to Suga with the question:

Murakami: Prime Minster Abe aims at an increase of $2 \%$ in the price index, well, actually what will be the percentage increase in wages?

Suga: Wages will increase more than the price index, employment will expand, this is the [kind of] economic policy we are working on now (Gekiron Kurosufaya, 2 March 2013).

Suga clearly does not answer the question. He states that wages will increase more than the price index but stops short of giving the exact figure. Considering the argument of the economics expert, Suga probably believes that he has to defend the economic policy of the government. On the one hand, he could challenge the knowledge of the expert. That might reflect badly on him, as the expert is a specialist in the field. On the other hand, if he accepts the expert's views as correct, he will admit that government policy will hurt the market. Under these circumstances, Suga prefers to provide a vague and indirect reply on behalf of the government, that the administration is working on increasing the price index and expanding employment.

In addition to energy/nuclear power and the economy, Diet members also tended to equivocate (especially on the sender, receiver, and the context dimensions) on issues such as the national security, above all in topics related to involvement in international conflicts, and the constitution. Consider the following extract, introduced already above, which is taken from an interview on national security and disarmament reduction with 
Kasai Akira, the JCP's Deputy Party Policy Committee. He is asked about the Japan Coast Guard:

Sorimachi: From the perspective of JCP, is the size of Japan Coast Guard today small?

Kasai: It is said that they do what is needed as a necessary police activity

(Puraimu Nyūsu, 22 November 2012).

Without doubt, Kasai does not answer the question about the scale of the Coast Guard. If he replies it is small (and thus indirectly advocates increasing in its size), it will be contrary to his party's opposition to increasing the military forces of Japan. If he replies it is big and implies that there is a need to reduce the size, he might be blamed for jeopardizing the security of Japan. In this communicative conflict, Kasai just utters something very unclear, almost like a cliché that 'they do what is needed'. Not only does he not give a complete reply, Kasai also, as mentioned, fails to express his own opinion; his words, 'It is said', can be interpreted as the way things are perceived either by his party or by the Japan Coast Guard. In any case, this is not his own personal view. Furthermore, his response seems to be addressed, not so much to the interviewer as to the general audience, ensuring them, in a sense, that as 'for the Coast Guard, I am told, they are doing what is to be done, so let's trust them'. This is an example of a question in which an interviewed politician equivocates along all the four Bavelas et al. (1990) dimensions with regard to a controversial and divisive issue - the size of the Japanese Self-Defense Forces.

Conspicuously, as appears in Table 3, when addressing questions on the consumption tax and financial affairs, Diet members' replies do not reflect their thoughts, aimed at groups or people other than the interviewer, and are confused, difficult to understand, along the sender, receiver, and the content dimensions. The following example on financial affairs is from an interview with Prime Minister Abe who does not reply to the question, in fact he declines to answer the question he was asked.

Murakami: There was a discussion on the strong and weak yen. Even under depreciation in the value of the yen when there is an increase in exports, as it was mentioned before, the importing costs will increase due to the value increase of the yen. The neutralization will offset the economic impact. I know it is hard, but can you explain to us Mr. Abe how you understand the value of the yen? What is the precise value of the yen [per dollar] that is safe and the value of yen that is dangerous?

Abe: Well, in this regard, if I can say right out, er-, I think is it very easy to understand also by everyone, er-, as the head of government, I wouldn't specify the exchange numbers, so to speak, this I would suggest, by all means, to invite an economist [to this studio] and ask him this question (Gekiron Kurosufaya, 9 March 2013). 
When asked about reconstruction efforts and questions involving the affected areas following the 2011 earthquake, Diet members equivocate on the sender and the receiver dimensions. Questions on Diet affairs management met with equivocal replies along the receiver and the context dimensions, although national level politicians tend to reveal their own opinion (sender dimension). In addition, Diet members avoid replying to questions (the context dimension) on issues such as the foreign policy/diplomacy, and intra-party politics, and address their replies to others than the interviewers (receiver dimension) when ask to focus on campaign strategies and policy beliefs and preferences' related questions.

Importantly, in this table, as in the following ones, the higher the beta figure is, the best predictor it is for equivocation. When looking at Table 3 on the reply to questions (the context dimension), the general inclination of national level politicians is to equivocate highly on issues regarding mostly energy issues (0.463), Diet affairs management (0.460), the constitution (0.441), the economy (0.436), and on the TPP (o.398). As the table further reveals regarding gender, men talk less clearly when replying to questions and women tend to reveal their thoughts more.

\section{Equivocation by local level politicians}

Table 4 reveals that the best predictor for equivocation among the local level politicians in the content dimension are questions regarding intra-party politics (0.990), the constitution (0.920), inter-party cooperation (0.901), and reconstruction efforts in the aftermath of the great earthquake (0.540). When replying to questions on foreign policy/diplomacy, local level politicians do not address the interviewers (even though they reveal their own thoughts) and do not reply directly to questions regarding such issues as inter-party cooperation, policy beliefs and preferences, and the constitution.

The following example is from an interview with Hashimoto, the Mayor of Osaka and JRP's representative, to illustrate how Hashimoto equivocates on the content as Tahara questions him about the merits of the current constitution:

Tahara: Next, I think, er-, I would add that, in this sense, after all, I think that in order to make the occupation [of Japan, between 1945 and 1952] easy to carry out, the [US] occupying forces design the constitution according to their convenience. Then, for example, what are in particular the benefits of having this constitution to this day?

Hashimoto: Regarding this, well, after all, er-, the point is that the Japanese people wonder what to do regarding their own country. Er-, they were not educated at all [in this regard]. They also didn't learn how much sweat is needed to secure the peace. They also didn't learn about the territorial disputes. In addition, they didn't learn either on the balance of power in the global community, especially in Asia, the diplomatic relations in East Asia, all these, well, they didn't even learn that they have to open and read books on modern history. After all, er-, I think they learn [internalized] that to be silent [to do 
Table 4. Local politicians' responses on issues during televised interviews

\begin{tabular}{|c|c|c|c|c|c|c|c|c|}
\hline & $\begin{array}{r}\text { Sen } \\
\text { Dimer }\end{array}$ & & $\begin{array}{r}\text { Rece } \\
\text { dimen }\end{array}$ & & $\begin{array}{r}\text { Cont } \\
\text { dimen }\end{array}$ & & $\begin{array}{r}\text { Cont } \\
\text { dimen }\end{array}$ & \\
\hline & Beta & S.E. & Beta & S.E. & Beta & S.E. & Beta & S.E. \\
\hline (Constant) & $\begin{array}{l}4.554^{* * *} \\
(10.935)\end{array}$ & 0.416 & $\begin{array}{l}3.993^{* * *} \\
(17.931)\end{array}$ & 0.223 & $\begin{array}{l}-0.098 \\
(-0.244)\end{array}$ & 0.402 & $\begin{array}{l}1.885^{* * *} \\
(3.336)\end{array}$ & 0.565 \\
\hline $\begin{array}{l}\text { Gender (female) } \\
\text { [29 questions] }\end{array}$ & $\begin{array}{l}-0.019 \\
(-0.068)\end{array}$ & 0.282 & $\begin{array}{c}0.204 \\
(1.352)\end{array}$ & 0.151 & $\begin{array}{c}0.102 \\
(0.374)\end{array}$ & 0.272 & $\begin{array}{l}-0.342 \\
(-0.895)\end{array}$ & 0.383 \\
\hline Age & $\begin{array}{l}-0.022^{* * *} \\
(-3.355)\end{array}$ & 0.007 & $\begin{array}{c}0.000 \\
(-0.095)\end{array}$ & 0.004 & $\begin{array}{l}0.033^{* * *} \\
(5.158)\end{array}$ & 0.006 & $\begin{array}{c}0.007 \\
(0.831)\end{array}$ & 0.009 \\
\hline $\begin{array}{l}\text { Constitution } \\
\text { [14 questions] }\end{array}$ & $\begin{array}{l}-0.517 \\
(-1.527)\end{array}$ & 0.339 & $\begin{array}{c}0.242 \\
(1.335)\end{array}$ & 0.181 & $\begin{array}{l}0.920^{* * *} \\
(2.814)\end{array}$ & 0.327 & $\begin{array}{l}1.242^{* * *} \\
(2.704)\end{array}$ & 0.459 \\
\hline $\begin{array}{l}\text { Foreign policy/Diplomacy } \\
\text { [45 questions] }\end{array}$ & $\begin{array}{l}-0.392^{*} \\
(-1.781)\end{array}$ & 0.220 & $\begin{array}{l}0.361^{* * *} \\
(3.068)\end{array}$ & 0.118 & $\begin{array}{c}0.277 \\
(1.301)\end{array}$ & 0.213 & $\begin{array}{l}-0.187 \\
(-0.625)\end{array}$ & 0.299 \\
\hline $\begin{array}{l}\text { Intra-party Politics } \\
\text { [5 questions] }\end{array}$ & $\begin{array}{l}-0.273 \\
(-0.493)\end{array}$ & 0.552 & $\begin{array}{l}0.621^{* *} \\
(2.102)\end{array}$ & 0.295 & $\begin{array}{c}0.990^{*} \\
(1.856)\end{array}$ & 0.533 & $\begin{array}{l}-0.181 \\
(-0.242)\end{array}$ & 0.749 \\
\hline $\begin{array}{l}\text { Campaign strategy } \\
\text { [4 questions] }\end{array}$ & $\begin{array}{l}-0.641 \\
(-1.074)\end{array}$ & 0.597 & $\begin{array}{c}0.279 \\
(0.874)\end{array}$ & 0.319 & $\begin{array}{l}1.750^{* * *} \\
(3.038)\end{array}$ & 0.576 & $\begin{array}{l}-0.360 \\
(-0.444)\end{array}$ & 0.809 \\
\hline $\begin{array}{l}\text { Reconstruction efforts } \\
\text { [38 questions] }\end{array}$ & $\begin{array}{l}0.746^{* * *} \\
(3.123)\end{array}$ & 0.239 & $\begin{array}{l}0.320^{* *} \\
(2.503)\end{array}$ & 0.128 & $\begin{array}{l}0.540^{* *} \\
(2.340)\end{array}$ & 0.231 & $\begin{array}{c}0.029 \\
(0.088)\end{array}$ & 0.324 \\
\hline $\begin{array}{l}\text { Policy beliefs and Preferences } \\
\text { [3 questions] }\end{array}$ & $\begin{array}{l}-0.760 \\
(-1.107)\end{array}$ & 0.686 & $\begin{array}{c}0.358 \\
(0.975)\end{array}$ & 0.367 & $\begin{array}{l}1.757^{* * *} \\
(2.652)\end{array}$ & 0.663 & $\begin{array}{l}2.070^{* *} \\
(2.223)\end{array}$ & 0.931 \\
\hline $\begin{array}{l}\text { Inter-party Cooperation } \\
\text { [10 questions] }\end{array}$ & $\begin{array}{l}-1.343^{* * *} \\
(-3.420)\end{array}$ & 0.393 & $\begin{array}{l}-0.074 \\
(-0.354)\end{array}$ & 0.210 & $\begin{array}{l}0.901^{* *} \\
(2.375)\end{array}$ & 0.379 & $\begin{array}{l}1.508^{* * *} \\
(2.831)\end{array}$ & 0.533 \\
\hline$F(9)$ & $4.558^{* * *}$ & & $1.837^{*}$ & & $6.130^{* * *}$ & & $.635^{* * *}$ & \\
\hline Adjusted $\mathrm{R}^{2}$ & 0.130 & & 0.034 & & 0.177 & & 0.064 & \\
\hline$N$ & 215 & & 215 & & 215 & & 215 & \\
\hline
\end{tabular}

Notes: ${ }^{* * *}: \mathrm{p}<0.01,{ }^{* *}: \mathrm{p}<0.05,{ }^{*}: \mathrm{p}<0.10$

Entries are unstandardized regression coefficients ( $b$ 's) and standard errors.

Figures in parenthesis indicate the $\mathrm{t}$-value. 
nothing] is the basis of ensuring the safety, and, after all, I think this has a great influence on education (Gekiron Kurosufaya, 6 April 2013).

In his reply, Hashimoto clearly does not answer the question (context dimension) about the merits that have been obtained by the existence of the constitution. He probably tries to relate the constitution to education, or lack of it, but ends up hinting that there was no education regarding the constitution, and that the constitution has an effect on education. But these ideas appear in his reply in a vague and implicit manner, and one has to read between the lines to get the nuance from his statement (content), addressed mostly to the general public (receiver). The fact that Hashimoto tries at the time of the interview to consolidate and widen the base of his political group nationwide may be the reason that he tries to be careful in what he says about either the merits or the demerits of the constitution in order not to upset potential supporters. This is despite the fact that as a lawyer he has clear ideas about the constitution, including the need to change it and its interpretation. In any case, while Hashimoto expresses his own views (sender), he equivocates on the context, content, and the receiver dimensions.

To further illustrate, consider the following example, coded under the category of policy beliefs: it comes from an interview with Ishihara Shintaro, the governor of Tōkyō, in the context of a talk on the era of post-LDP factions' politics and how this can affect the nurturing of the country's leaders: ${ }^{3}$

Yagi: What do you think about it [the era of post-LDP factions politics]?

Ishihara: Well, one reason I dislike the LDP is its factions, not only this but also the fact that the grandson or a son of the prime minister easily become prime minister himself. This is, well, I dislike this sort of things, which cannot be accepted in the world of art (Puraimu Nyūsu, 16 May 2012).

As a former LDP member, who also headed a faction within the party, Ishihara refrained from replying to the question. Alternatively, he criticizes the fact that relatives to prime ministers are easily selected to follow up in positions of their fathers. His reply seems to be oriented to the world of politics, expressing perhaps his dissatisfaction from the growing trend of hereditary politics (even though his own son is also a Diet member).

Finally, the table also suggests in regard to age that younger local politicians are most likely to reveal their thoughts and opinions, while older politicians one talk less clearly.

\section{Equivocation by non-politicians}

Last, as detailed in Table 5, the non-politicians, including university professors and critics, experts on economy, society, and other important issues that are invited to share their expertise in the studio, tend to equivocate when replying to questions

3 The Intra-party factions have dominated LDP since its inauguration in 1955. During postwar years factions have been regarded as institutionalized structures designed for allocation of campaign finances, party positions, and cabinet appointments. 
Table 5. Non-politicians' responses on issues during televised interviews

\begin{tabular}{|c|c|c|c|c|c|c|c|c|}
\hline & $\begin{array}{r}\text { Sen } \\
\text { Dime }\end{array}$ & & $\begin{array}{r}\text { Rece } \\
\text { dimen }\end{array}$ & & $\begin{array}{r}\text { Con } \\
\text { dimer }\end{array}$ & & $\begin{array}{r}\text { Cont } \\
\text { dimen }\end{array}$ & \\
\hline & Beta & S.E. & Beta & S.E. & Beta & S.E. & Beta & S.E. \\
\hline (Constant) & $\begin{array}{l}3.004^{* * *} \\
(12.723)\end{array}$ & 0.236 & $\begin{array}{l}3.586^{* * *} \\
(27.881)\end{array}$ & 0.129 & $\begin{array}{l}1.479^{* * *} \\
(6.361)\end{array}$ & 0.232 & $\begin{array}{l}1.730^{* * *} \\
(5.598)\end{array}$ & 0.309 \\
\hline $\begin{array}{l}\text { Gender (female) } \\
\text { [127 questions] }\end{array}$ & $\begin{array}{l}-0.558^{* * *} \\
(-4.029)\end{array}$ & 0.138 & $\begin{array}{l}0.313^{* * *} \\
(4.147)\end{array}$ & 0.075 & $\begin{array}{l}0.289^{* *} \\
(2.119)\end{array}$ & 0.136 & $\begin{array}{l}0.170 \\
(0.936)\end{array}$ & 0.181 \\
\hline Age & $\begin{array}{l}-0.001 \\
(-0.285)\end{array}$ & 0.004 & $\begin{array}{l}0.006^{* * *} \\
(2.889)\end{array}$ & 0.002 & $\begin{array}{l}0.009 * * \\
(2.531)\end{array}$ & 0.004 & $\begin{array}{c}0.004 \\
(0.920)\end{array}$ & 0.005 \\
\hline $\begin{array}{l}\text { National security } \\
\text { [35 questions] }\end{array}$ & $\begin{array}{c}0.252 \\
(1.264)\end{array}$ & 0.199 & $\begin{array}{l}-0.314^{* * *} \\
(-2.892)\end{array}$ & 0.108 & $\begin{array}{c}0.033 \\
(0.166)\end{array}$ & 0.196 & $\begin{array}{l}0.721^{* * *} \\
(2.767)\end{array}$ & 0.261 \\
\hline $\begin{array}{l}\text { Foreign policy/Diplomacy } \\
\text { [152 questions] }\end{array}$ & $\begin{array}{l}-0.011 \\
(-0.104)\end{array}$ & 0.110 & $\begin{array}{l}-0.151^{* *} \\
(-2.518)\end{array}$ & 0.060 & $\begin{array}{c}0.168 \\
(1.555)\end{array}$ & 0.108 & $\begin{array}{l}0.355^{* *} \\
(2.470)\end{array}$ & 0.144 \\
\hline $\begin{array}{l}\text { Economy } \\
\text { [168 questions] }\end{array}$ & $\begin{array}{l}0.391^{* * *} \\
(3.619)\end{array}$ & 0.108 & $\begin{array}{l}-0.117^{* *} \\
(-1.985)\end{array}$ & 0.059 & $\begin{array}{l}0.233^{* *} \\
(2.184)\end{array}$ & 0.106 & $\begin{array}{r}0.242^{*} \\
(1.710)\end{array}$ & 0.141 \\
\hline $\begin{array}{l}\text { TPP } \\
\text { [97 questions] }\end{array}$ & $\begin{array}{l}-1.056^{* * *} \\
(-5.557)\end{array}$ & 0.190 & $\begin{array}{l}-0.140 \\
(-1.353)\end{array}$ & 0.103 & $\begin{array}{l}0.057 \\
(0.303)\end{array}$ & 0.187 & $\begin{array}{l}0.636^{* *} \\
(2.558)\end{array}$ & 0.249 \\
\hline $\begin{array}{l}\text { Reconstruction efforts } \\
\text { [37 questions] }\end{array}$ & $\begin{array}{r}0.368^{*} \\
(1.807)\end{array}$ & 0.204 & $\begin{array}{c}0.044 \\
(0.398)\end{array}$ & 0.111 & $\begin{array}{r}0.377^{*} \\
(1.882)\end{array}$ & 0.201 & $\begin{array}{c}0.070 \\
(0.263)\end{array}$ & 0.267 \\
\hline $\begin{array}{l}\text { Diet affairs Management } \\
\text { [65 questions] }\end{array}$ & $\begin{array}{c}0.447 \\
(0.886)\end{array}$ & 0.505 & $\begin{array}{l}-0.869^{* * *} \\
(-3.158)\end{array}$ & 0.275 & $\begin{array}{l}-0.526 \\
(-1.058)\end{array}$ & 0.497 & $\begin{array}{l}-0.146 \\
(-0.221)\end{array}$ & 0.661 \\
\hline $\begin{array}{l}\text { Policy beliefs and Preferences } \\
\text { [21 questions] }\end{array}$ & $\begin{array}{l}-0.269 \\
(-0.415)\end{array}$ & 0.647 & $\begin{array}{c}0.036 \\
(0.102)\end{array}$ & 0.352 & $\begin{array}{c}0.256 \\
(0.403)\end{array}$ & 0.637 & $\begin{array}{l}2.648^{* * *} \\
(3.127)\end{array}$ & 0.847 \\
\hline Public opinion & -0.445 & 0.400 & -0.038 & 0.218 & -0.121 & 0.394 & $1.020^{*}$ & 0.523 \\
\hline [8 questions] & $(-1.112)$ & & $(-0.175)$ & & $(-0.308)$ & & $(1.949)$ & \\
\hline$F(10)$ & $8.590^{* * *}$ & & $5.363^{* * *}$ & & $1.645^{*}$ & & $2.976^{* * *}$ & \\
\hline Adjusted $\mathrm{R}^{2}$ & 0.097 & & 0.051 & & 0.008 & & 0.024 & \\
\hline$N$ & 808 & & 808 & & 808 & & 808 & \\
\hline
\end{tabular}

Notes: Significance levels:***: $p<0.01,{ }^{* *}: p<0.05,{ }^{*}: p<0.10$.

Entries are unstandardized regression coefficients ( $b$ 's) and standard errors.

Figures in parenthesis indicate the $\mathrm{t}$-value. 
on the economy (in the sender, content, and context dimensions), the reconstruction efforts (sender and context), and do not answer questions (context dimension) regarding foreign policy, TPP, policy beliefs and preferences, public opinion, and national security. In fact, national security and the TPP-related questions are the best predictors of nonpoliticians' equivocation in answering questions.

Consider the following extract from an interview with Yoshizaki Tatsuhiko, the chief economist and executive vice-director of Sojitz Research Institute. The focus of the interview is on the situation in France following the election of May 2012 when President Nicolas Sarkozy was defeated. In response to a question on how he sees the election, Yoshizaki states that in this election he felt that Sarkozy was a little disliked. He attributed this to his character, the fact that immediately after being appointed to the presidency in May 2007 he went on an early vacation, enjoyed the time on a boat, and was involved in other extravagant activities the public disliked, and that he felt pretty sorry about Sarkozy. Then he is asked:

Tahara: Well, and [Mr. Sarkozy] is not a pure French [correct?]

Yoshizaki; Yes, this is true. He is a child of immigrants.

Tahara: Do children of immigrants in France experience discrimination even today?

Yoshizaki: Well, mentioning this, even Napoleon was born in Corsica. Er-., well, France knew how to use such a person very efficiently in its history, doesn't it?

(Gekiron Kurosufaya, 26 May 2012).

Yoshizaki does not answer the question as to whether children of immigrants suffer discrimination in France today. Instead, he mentions that Napoleon also emigrated to France (and probably did not experience discrimination). He probably cannot answer the question he was asked in a negative way because of the increasing information on young adults of immigrant origin in France that are more likely to be outside the educational system, and not be economically active or to enter the labor market, as these are affected among other things by the discrimination they face. Alternatively, if Yoshizaki replies in a positive way, he will have to explain how he can be sympathetic to Sarkozy, as Sarkozy's rightwing anti-immigrant rhetoric is blamed for the discrimination that has worsened in recent years against the third- and fourthgeneration children of immigrants, and for the widespread tension among immigrants in general. A response such as 'I don't know' may make him looks bad; as an expert he is expected to reply to a question in an area that he has expertise. Yoshizaki tries thus to defend his own personal face, avoiding replying by 'I don't know' and instead just talks about Napoleon and his success in French history.

Last as shown in the table, older people equivocate on the receiver and the content dimensions; in terms of gender, men tend to equivocate more than women on the 
receiver and the content dimensions, while women disclose more their thought (sender) on various issues.

\section{Conclusions}

The results of this study show that when Japanese politicians and non-politicians respond to questions during televised interviews, they are less likely to disclose their personal thoughts and opinions, tend often to address people other than the interviewers, incline to talk unclearly, and habitually do not directly answer the questions they have been asked. Generally speaking, politicians equivocate significantly more than non-politicians, and national level Diet members equivocate significantly more than local level politicians.

Members of the three groups of politicians and non-politicians equivocate regarding both non-issues (i.e., knowledge of a certain topic, views on individuals' and groups' activities and perceptions, and insight on political process and commitment) and political and social issues. In comparison to non-issues, however, interviewees tend to equivocate more on at least three dimension (receiver, content, and context) when they are asked to share their opinions regarding important issues that are on the public agenda.

In this study, we identify the issues that members of each group tend to significantly equivocate on most often during televised interviews. There is no doubt that these issues are at the heart of the public debate, they are sensitive and conflict-ridden matters to both citizens as well as to decision-makers, politicians, and government officials. Our analysis indicates diversity in the patterns of equivocation among interviewees: First, members of all three groups examined here tend unanimously to equivocate, on this dimension or another, in respect to three explicit issues: Foreign policy/diplomacy, reconstruction efforts, and policy beliefs and preferences. These issues seem to be the most divisive issues for politician and non-politicians alike to the extent that questions regarding these topics are most likely to meet with equivocal responses from either group member. Second, politicians on both the national and local levels tend collectively to provide indirect, ambiguous, tangential, even evasive responses when they are approached on such issues as the constitution, intra-party politics, and campaign strategies. Third, members of the national Diet along with non-politicians equivocate together on such topics as national security, economy, TPP, and Diet affairs management. In addition, only Diet members equivocate when replying to questions on consumption tax/financial affairs and on questions regarding energy and nuclear power related to the affected areas following the 2011 Great East Japan earthquake and tsunami; Only local level politicians equivocate on inter-party cooperation related questions; and non-politicians is the only group that equivocate on public opinion.

Comparatively, Diet members have the largest number of issues (12 out of the 19 clustered here) that they equivocate about when replying to questions, followed by non-politicians (8), and local level politicians (7). Thus, not only national Diet 
members tend to equivocate significantly more than any other group of interviewees, they also tend to equivocate more often regarding important social and political issues. This may reflect the fact that national level politicians are put over and over again in communicative conflicts where they are confronted by challenging interviewers to choose among undesirable alternatives that may damage their own or their group image, or negatively affect their supporters.

Against such an option and in order to refrain from making face-damaging responses-- to use Bull et al. (1996) words - that is, responses which make themselves and/or their political allies look bad, and/or constrain their future freedom of action, interviewees in general tend to defend three 'faces': their own 'face' (e.g., as a global issues expert, as a prime minister), their political group or government 'face' (as the head of the party's committee, as a minister), and significant others' 'face' (the prime minister, potential voters).

Consequently they equivocate: they reveal views and stances on important issues of those members whom they work with, including colleagues from political parties and factions, and other officials and the media; they aim their replies not at the interviewer but rather at the 'overhearing audience', their supporters, the electorate, and members of other political groups and officials who are their partners in the political game; their responses contain less explicit and less easy-to-understand remarks as they confine their talk to a bland statement or difficult to grasp double talk; and through their replies they both challenge the nature of the questions being asked and show they will not respond in the expected fashion and, thus, they recognize the question but do not answer on it, reply by reflecting the question back to the interviewer, attack the question or the interviewer, and change the focus of the question and derive on another issue. All the above suggests that equivocation is intrinsically detrimental to political interviews, thereby calling into question both their role and effectiveness in sustaining and promoting meaningful political dialogue.

\section{Acknowledgments}

We are grateful to Imai Masae, Ota Monami, Takeda Yuki, Sawada Kanae, Adachihara Yui, and Hatani Iri for transcribing the interviews, and to Ishimaru Atsushi and Misumi Naoki for assistance in coding the data. We also wish to express sincere gratitude to Professor Ehud Harari for reading an earlier draft of this paper and offering very helpful comments.

Financial support during this study came through a Grant-in-Aid for Scientific Research awarded to the first author by the Japanese Ministry of Education, Culture, Sports, Science, and Technology (2012-2015) and through a travel grant awarded to the third author from the Great Britain Sasakawa Foundation (May 2015).

\section{About the authors}

Ofer Feldman ( $\mathrm{PhD}$, University of Tokyo, Japan) is a professor of political psychology and behavior at Doshisha University, Kyoto, Japan. He is the author, editor, 
and co-editor of 13 books and monographs, of more than 90 journal articles and book chapters, and more than 100 encyclopedia items, in the fields of political psychology, communication studies, and Japanese politics.

Ken Kinoshita (PhD, Doshisha University, Japan) is an assistant of Organization for Research Initiatives and Development at the Faculty of Policy studies, Doshisha University.

Peter Bull (PhD, University of Exeter, United Kingdom) is a Reader in the Department of Psychology at the University of York, United Kingdom. He has more than 100 academic publications, principally in the form of articles in internationally recognized academic journals. He has also written five books, as well as numerous book chapters. His published output has been primarily concerned with the analysis of interpersonal communication.

\section{References}

Bavelas, J. B., A. Black, L. Bryson, and J. Mullett (1988), 'Political Equivocation: A Situational Explanation', Journal of Language and Social Psychology, 7: 137-45.

Bavelas, J. B., A. Black, N. Chovil, and J. Mullett (1990), Equivocal Communication, Newbury Park, CA: Sage.

Bull, P. (1994), 'On Identifying Questions, Replies and Non-Replies in Political Interview', Journal of Language and Social Psychology, 13: 115-31.

Bull, P. (2003), The Microanalysis of Political Communication, London: Routledge.

Bull, P. (2008), "'Slipperiness, Evasion and Ambiguity": Equivocation and Facework in Non-Committal Political Discourse', Journal of Language and Social Psychology, 27: 333-44.

Bull, P., J. Elliott, D. Palmer, and L. Walker (1996), 'Why Politicians Are Three-Faced: The Face Model of Political Interviews', British Journal of Social Psychology, 35: 267-84.

Bull, P. and K. Mayer (1993), 'How Not to Answer Questions in Political Interview', Political Psychology, 4: 651-66.

Clayman, S. E. and J. Heritage (2002), The News Interview: Journalists and Public Figures on the Air, Cambridge: Cambridge University Press.

Cohen, J. (1960), 'A Coefficient of Agreement for Nominal Scales', Educational and Psychological Measurement, 20: $37-46$.

Feldman, O. (2004), Talking Politics in Japan Today. Brighton; UK: Sussex Academic Press.

Feldman, O., K. Kinoshita, and P. Bull (2015), Culture or Communicative Conflict? The Analysis of Equivocation in Broadcast Japanese Political Interviews. Journal of Language and Social Psychology, 34: 65-89.

Furo, H. (2001), Turn-Taking in English and Japanese: Projectability in Grammar, Intonation, and Semantics, New York: Routledge.

Harris, S. (1991), 'Evasive Action: How Politicians Respond to Questions in Political Interviews', in P. Scannell (ed.), Broadcast Talk, London: Sage, pp. 76-99.

Heritage, J. (1985), 'Analyzing News Interviews: Aspects of Talk for an Overhearing Audience', in T. A. van Dijk (ed.), Handbook of Discourse Analysis, Vol. III, New York: Academic Press, pp. 95-119.

Hu, Y. (1999), A Study of Question Evasion in Mandarin Political Discourse, Taipei: National Taiwan Normal University.

Huang, Y. (2009), 'A Study of Hedge Strategies in Taiwan Political Discourse', in E. Weigand (ed.), Dialogue Analysis XI : Proceedings of the 11th IADA Conference on 'Dialogue Analysis and Rhetoric', University of Münster, March 26-30, 2007, Iada.online.series, pp. 155-80.

Jucker, J. (1986), News Interviews: A Pragmalinguistic Analysis, Amsterdam: Gieben.

Tanaka, L. (2004), Gender, language, and culture: A study of Japanese interview discourse. Amsterdam, Netherlands: John Benjamins. 